\title{
The stratigraphy of the youngest part of the Kimmeridge Clay Formation (Upper Jurassic) of the Dorset type area.
}

\section{Ramues Gallois and Steve Etches}

Gallois, R. W. and S. Etches. 2001. The stratigraphy of the youngest part of the Kimmeridge Clay (Upper Jurassic) of the Dorset type area. Proceedings of the Geologists' Association, 112, 169-182. The lithostratigraphy of the youngest part of the Kimmeridge Clay of the stratotype section at Houns-tout/Chapman's Pool in south Dorset is described in detail for the first time, and is the correlated with other current exposures in south Dorset and with borehole sequences in more distant areas. The stratotype section, albeit deeply weathered in part, is the only complete succession in Britain through this late Jurassic interval. It remains of key importance to international correlation of the Boreal, Sub-boreal and Tethyan faunal provinces at this stratigraphical level, and to the resolution of the debate concerning the boundaries of the Kimmeridgian, Tethyan and Bolonian stages.

\section{INTRODUCTION}

The type area for the Kimmeridge Clay Formation and the Kimmeridgian Stage is a narrow coastal strip in south Dorset. The lower part of the formation, including a candidate stratotype for the Oxfordian-Kimmeridgian stage boundary, is exposed in a series of low cliffs at Ringstead Bay [750 $820]^{1}$, and the upper part of the formation in continuous cliff and foreshore sections at and adjacent to Kimmeridge Bay [910 790] (Figure 1). The stratigraphy of these sections has been described in detail (see Cox \& Gallois, 1981 for summary) up to the level of the Rotunda Nodules, a prominent marker band about $80 \mathrm{~m}$ below the top of the formation. The beds above the Rotunda Nodules are poorly exposed in comparison with much of the remainder of the formation, and there is little published information on their stratigraphy.

These highest beds, including the junction with the overlying Portland Group, are exposed in a series of discontinuous sections around Houns-tout Cliff and Chapman's Pool at the eastern end of the type section. The junction of the Kimmeridge Clay and the Portland Sand Formation has been taken by most authors since the time of Arkell (1933) at the base of the Massive Bed, a 2 m-thick bed of calcareously cemented, very fine-grained sandstone that forms a prominent marker band in Houns-tout Cliff. Much of the same succession is also exposed below Gad Cliff [880 794], 5km to the west of Houns-tout, but in a series of deeply weathered, isolated sections that are difficult to 
correlate with one another. Parts of the youngest Kimmeridge Clay sequence have been exposed from time to time at beach level below Dungy Head [817 798], 1km west of Lulworth Cove, on the degraded slopes above Ringstead Bay [762 816], and below the Portland Group cliffs at Grove Point [706 722] and West Weare Cliff [682 724] on the Isle of Portland (Figure 1). No section has been recorded at this stratigraphical level in the inland outcrop that runs westwards from Ringstead Bay to Abbotsbury.

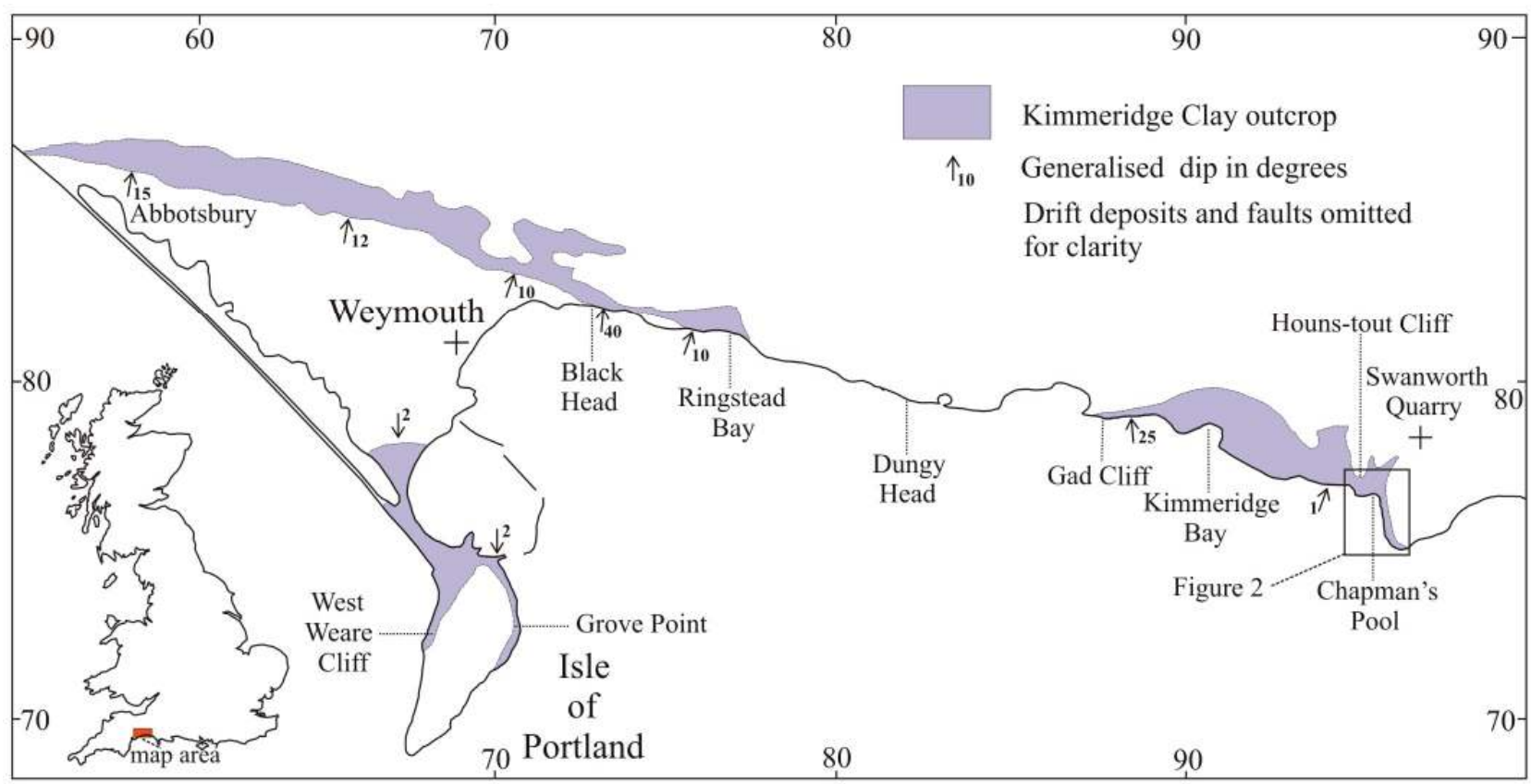

Figure 1. Key localities in the youngest part of the Kimmeridge Clay (Rotunda and Fittoni zones) in south Dorset.

The Kimmeridge Clay has been extensively studied at outcrop and in borehole sections in eastern and southern England. The formation has been divided into 49 chronostratigraphical units (referred to as $\mathrm{KC} 1$ to $\mathrm{KC} \mathrm{49)}$ on the basis of a combination of lithological and palaeontological features, and geophysical-log characteristics (see Gallois, 2000 for summary). These units span the ammonite-based Baylei to Pectinatus zones of the Kimmeridgian Stage sensu anglico (Callomon \& Cope, 1995). The chronostratigraphical classification did not extend to the highest zones, Pallasioides, Rotunda and Fittoni, largely because there were insufficient sections at those stratigraphical levels to be able to make the correlations necessary to identify laterally persistent isochronous events. In 1997, the upper part of the Kimmeridge Clay was continuously cored in two boreholes at Swanworth Quarry [9675 7823], 2km from its outcrop in the cliffs at Houns-tout (Gallois, 1998). Comparison of the outcrop section described below with that proved in the

\footnotetext{
${ }^{1}$ All localities fall in 100-km grid square SY unless otherwise stated.
} 
Swanworth Quarry borehole cores enabled the chronostratigraphical classification to be extended (KC 50 to KC 63) to the top of the formation (Gallois, 2000).

The highest part of the Kimmeridge Clay can be broadly divided into two: a lower part consisting of highly calcareous mudstones and silty mudstones, referred to in the earlier literature as the Rotunda Shales, and an upper more-silt-rich part for which the name Hounstout Silt Member has been proposed (Gallois, 1998). The Hounstout Silt can itself be divided into three parts: a lower part (in part the Lingula Shales and Rhynchonella Marls of Buckman, 1926 and Arkell, 1933), the Hounstout Clay (cf the Hounstout Clay of Arkell, 1933) and an Upper Hounstout Silt (cf the Hounstout Marl of Arkell, 1933). The Rotunda/Fittoni zones sequence is pyritic at most levels and this has contributed to its deeply weathered state in the Houns-tout sections. Calcareous fossils, other than belemnites, oysters, rhynchonellid brachiopods and echinoid spines, are mostly poorly preserved: secondary gypsum and 'sulphur'-coated surfaces are common. Sedimentary structures have largely been destroyed within much of the sequence by bioturbation in which the burrowing is commonly picked out by linings and infillings of pale silt in a darker, more argillaceous matrix. Despite these limitations, the broader lithological features can be picked out together with several lithologically distinctive marker bands that can be recognised in other sections in south Dorset.

\section{DESCRIPTIONS OF THE SOUTH DORSET EXPOSURES}

\section{Houns-tout Cliff/Chapman's Pool}

The highest part of the Kimmeridge Clay is exposed in deeply weathered cliffs that overlook Egmont Bight [948 772] and Chapman's Pool [995 771], below St Alban's Head [958 756], and in sections separated by landslip and collapsed strata below Houns-tout Cliff [948 773 to 953 772] (Figure 2). Taken together, these sections expose the Rotunda Nodules and the overlying beds up to and including the base of the Portland Sand. Despite the presence of large exposures that provide unbroken sections through much of the succession, it is not easy to obtain an accurate total thickness. The presence of large landslips and deep weathering (the key sections are above the effects of marine erosion) make it difficult to identify the minor lithological variations that are necessary for detailed correlation between the more fragmentary exposures.

Blake (1875) estimated the thickness of the beds between his Bed 2 (a prominent oil shale seam about $3 \mathrm{~m}$ below the Rotunda Nodules) and the top of the Kimmeridge Clay in the Houns-tout sections to be about 55m. Arkell (1947, p. 71) measured a total thickness of 71m (230ft); Cope (1978) and Townson (1975) reported thicknesses of $72 \mathrm{~m}$ and $65 \mathrm{~m}$ respectively for the same beds. 
Attempts by the present authors to collect accurately located palaeontological samples proved difficult because the above references contain only the simplest lithological descriptions. For example, the Hounstout Clay is described as a "clay" whose upper and lower boundaries are marked by lines of seepage. Comparison of the Arkell (1947) and Cope (1978) thicknesses (Table 1) shows that different lines of seepage, from several available on the lower Houns-tout slopes, were taken for both boundaries by these authors.

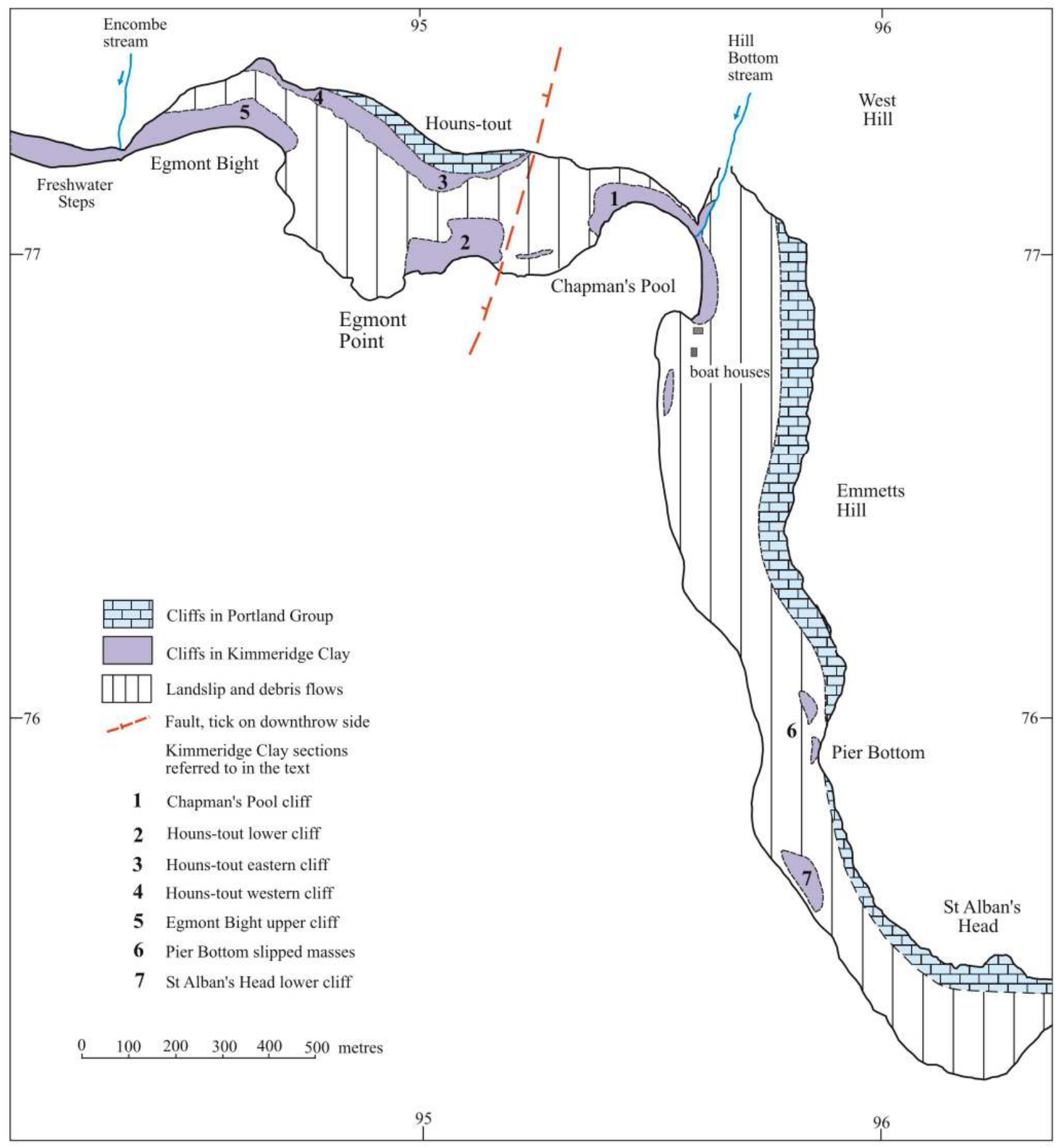

Figure 2. Exposures in the youngest Kimmeridge Clay (Rotunda and Fittoni zones) in the Hounstout to St Alban's Head area. 
The Houns-tout sections have been re-measured with an emphasis on lithological description and the identification of marker bands that might be recognisable in deeply weathered sections. The new measurements suggest that up to $10 \mathrm{~m}$ of strata are missing from the middle part (Lingula Shales to Hounstout Clay) of the previously published sections, probably due to miscorrelation in the most disturbed and poorly exposed part of the sequence. Correlation of the outcrop succession with that subsequently proved in the continuously cored Swanworth Quarry No.1 and 2 boreholes [9678 7823] (Gallois, 1998), drilled 2km NE of Houns-tout Cliff, confirmed the outcrop measurements (Figure 3). Several thin marker bands that had been recorded as deeply rotted lithologies at outcrop were present as distinctive lithologies in the boreholes. Notable among these are thin beds of bituminous mudstone/oil shale (the 'lower' and 'upper bituminous beds') and thin beds of dark grey, shelly pyritic mudstone, all of which give rise to distinctive high-gammaray/low-sonic signatures in the geophysical logs (Figure 3).

The following composite sequence was measured in the Houns-tout and Chapman's Pool exposures. The ammonite determinations are taken from Cope (1978), which is still the only detailed account of the ammonite faunas in this part of the succession.

\begin{tabular}{|c|c|c|c|c|c|}
\hline \multirow{2}{*}{$\begin{array}{c}\text { Zone } \\
\text { Cope, } 1978^{1}\end{array}$} & \multicolumn{2}{|c|}{ This account } & \multirow{2}{*}{$\begin{array}{r}\text { Cope, } 1978 \\
\text { Massive Bed } \\
\end{array}$} & \multicolumn{2}{|c|}{ Arkell, 1933;1947 } \\
\hline & Portland Group & Massive Bed & & Massive Bed & Portland Beds \\
\hline \multirow{5}{*}{ Fittoni } & $\begin{array}{l}\text { Upper } \\
\text { Hounstout } \\
\text { Silt }\end{array}$ & 17.9 & \multirow{2}{*}{$\begin{array}{l}\mathrm{HM} \\
21.0\end{array}$} & \multirow[t]{2}{*}{$\begin{array}{l}\mathrm{HM} \\
13.7\end{array}$} & $\begin{array}{l}\text { Hounstout Marl } \\
\text { (HM) }\end{array}$ \\
\hline & \multirow{3}{*}{$\begin{array}{l}\text { Hounstout } \\
\text { Clay }\end{array}$} & \multirow{3}{*}{17.8} & & & $\begin{array}{c}\text { Hounstout Clay } \\
\text { (HC) }\end{array}$ \\
\hline & & & $\begin{array}{l}\mathrm{HC} \\
8.4\end{array}$ & $\underset{6.1}{\mathrm{RM}}$ & Rhynchonella Marls (RM) \\
\hline & & & $\begin{array}{c}\text { Upper } \\
\text { RM\&LS } \\
8.0\end{array}$ & $\begin{array}{l}\mathrm{LS} \\
11.4\end{array}$ & $\begin{array}{l}\text { Lingula Shales } \\
\text { (LS) }\end{array}$ \\
\hline & \multirow{2}{*}{$\begin{array}{l}\text { Lower } \\
\text { Hounstout } \\
\text { Silt }\end{array}$} & \multirow[b]{2}{*}{23.1} & \multirow{2}{*}{$\begin{array}{l}\text { Lower } \\
\text { RM\&LS } \\
15.0\end{array}$} & \multirow{2}{*}{$\begin{array}{l}\mathrm{RC} \\
30.5\end{array}$} & \\
\hline $\begin{array}{l}\text { no ammonite } \\
\text { recorded }\end{array}$ & & & & & \multirow{2}{*}{$\begin{array}{c}\text { Rotunda Clays (RC) } \\
\text { including } \\
\text { Rotunda Nodules }\end{array}$} \\
\hline \multirow{3}{*}{ Rotunda } & \multirow{4}{*}{$\begin{array}{l}\text { Upper } \\
\text { Kimmeridge } \\
\text { Clay } \\
\text { undivided }\end{array}$} & 21.8 & $\begin{array}{c}\text { RC } \\
19.6 \\
\text { Rotunda Nodules }\end{array}$ & Rotunda Nodules & \\
\hline & & Rotunda Nodules & Blake's Bed 2 & Blake's Bed 2 & \multirow{3}{*}{$\begin{array}{l}\text { Crushed } \\
\text { Ammonoid } \\
\text { Shales }\end{array}$} \\
\hline & & Blake's Bed 2 & & & \\
\hline $\begin{array}{l}\text { Pallasioides } \\
\text { (pars) }\end{array}$ & & & & & \\
\hline
\end{tabular}

Table 1. Nomenclature of the highest part of the Kimmeridge Clay at Houns-tout/Chapman's Pool.

\section{Portland Sand Formation:}

Massive Bed; fine-grained, calcareous sandstone 


\section{Kimmeridge Clay Formation \\ Hounstout Silt Member \\ Upper Hounstout Silt: \\ KC 63}

Mudstone, silty and very silty, and muddy siltstone, thickly interbedded; medium and brownish grey when fresh, becoming paler with increasing silt content; highly bioturbated at many levels with Teichichnus, Rhizocorallium, Arenicolites and other burrows picked out by pale silt content; poorly preserved bivalves and ammonites in lower $2.0 \mathrm{~m}$ including Virgatopavlovia hounstoutensis Cope, V. sp. aff. fittoni Cope and Pavlovia spp. indet. ....6.00m Siltstone, muddy and very silty mudstone, thickly interbedded; fauna as bed above; bioturbated throughout; weathering to yellow and cream; calcareously cemented in part and giving rise to prominent bluffs; fauna as bed above .....2.30m

Siltstones and mudstones, as above; alternations of silt-dominated and mudstone-dominated beds mostly 1.1 to $1.7 \mathrm{~m}$ thick; fauna and bioturbation as bed above; silt-rich beds form prominent bluffs and local seepage lines; prominent seepage line at base

\section{Hounstout Clay: \\ KC 62}

Mudstone, silty and very silty with a few interbeds of muddy siltstone; medium grey, paler where more silty; highly bioturbated as bed above with burrows exceptionally well preserved in more siltrich horizons; fauna as bed above including Virgatopavlovia hounstoutensis, $V$. sp. aff. fittoni and Pavlovia spp.; thin (up to $0.4 \mathrm{~m}$ ), deeply weathered organic-rich bed in lower part forms coarsely fissile rib $5 \mathrm{~m}$ above base; base taken at top of bituminous mudstone .....12.70m

\section{KC 61}

Bituminous mudstone/oil shale, pyritic, brown and greyish brown; deeply weathered but forming prominent ribs; two seams separated by and underlain by pale grey highly calcareous mudstone with subconchoidal weathering; base taken at top of prominent siltstone rib

\section{Lower Hounstout Silt: \\ KC 60}

Siltstone, muddy, and silty and very silty mudstones, mostly in beds 0.10 to $0.40 \mathrm{~m}$ thick that form coarsening upward rhythms; seven prominent rhythms form upper part of unit; siltstones commonly form harder ribs, some with calcareously cemented burrowfills; highly bioturbated throughout; base taken at top of thin bituminous bed

\section{KC 59}

Siltstone, muddy and silty mudstone; rhythmically interbedded as $\mathrm{KC} 60$; thin $(0.05$ to $0.15 \mathrm{~m})$, laminated brownish grey bituminous mudstone with common pyritized oysters and other bivalves forms prominent rib at top of unit; siltstone forms similar rib at base .....2.40m Interbedded silty mudstone and siltstone; mostly poorly accessible or on debris-covered bench .....7.60m Cidarid Siltstone: siltstone, tough, pale grey; rich and diverse fauna including oysters, Entolium, Pachyteuthis, distinctive flat spines of Cidaris bolonensis Wright and common rhynchonellid brachiopods including Rhynchonella cf. portlandica Blake and Septaliphoria cf. septentrionalis Childs; marked lithological contrast and bioturbated surface at base ....0.30m

\section{Upper Kimmeridge Clay (undivided):} KC 58 
Mudstone, medium and pale grey, highly calcareous, becoming progressively more silty in highest part; interbeds of very pale grey mudstone with subconchoidal weathering at several levels; two or more thin (10 to $20 \mathrm{~mm}$ ) beds of dark grey, fissile shelly mudstone with abundant crushed bivalves; small oysters, 'Astarte', Oxytoma, Protocardia, Thracia scattered throughout and common at some levels; Pavlovia rotunda (Sowerby), $P$. spp. indet; $P$. concinna (Neaverson), $P$. aff. concinna in lower 13m: base taken at top of line of burrowfill nodules

\section{KC 57}

Mudstone, medium and pale grey, highly calcareous with subconchoidal weathering in part; line of large (up to $0.1 \times 0.2 \mathrm{~m}$ ) dense calcareous burrowfill nodules at top enclosing bivalves and rare Pavlovia; line of similar, but smaller nodules at base commonly containing well preserved Pavlovia, including P. concinna, P. rotunda and P. rotunda gibbosa (Buckman)......3.10 to 3.30m

\section{KC 56}

Mudstone, medium and pale grey, as bed above; Pavlovia concinna, $P$. rotunda, $P$. sp. B of Cope 1978 and $P$. spp. indet; plaster of large, crushed 'pavlovids' in lower part; base taken at top of oil shale

\section{KC 55}

Oil shale in two seams separated by calcareous mudstone (Blake's Bed 2)

Mudstone, thinly interbedded, dark and medium grey; erosion surface at base overlain by the Chapman's Pool Pebble Bed, a gritty, shell-rich pebble bed with phosphatised, pavlovid-bodychamber pebbles, abundant Pachyteuthis, oysters and other bivalves at base: and crushed and partially phosphatized Pavlovia including Pavlovia concinna, P. sp. nov. aff. varicostata Ilovaisky, P. rotunda, P. sp. B of Cope 1978

Although the lithology of this part of the Kimmeridge Clay appears at first sight to be relatively uniform, the main lithological units and several of the marker bands have a pronounced affect on the shape of the cliffs (Figure 4). The highly calcareous mudstones of the Rotunda Zone (KC 55 to 58) form steep cliffs or slopes that are, in consequence, well exposed at Chapman's Pool/Hounstout, St Alban's Head, Egmont Bight and Gad Cliff (Figure 5).

The base of the Lower Hounstout Silt is marked by a sharp upward decrease in slope angle to a debris-covered slope in which there are few exposures. A prominent rib and line of seepage at the junction marks the outcrop of the lithologically distinctive, shelly Cidarid Siltstone. The lower part of the Lower Hounstout Silt is poorly exposed. At the western end of Houns-tout much of it crops out on a broad bench, the site of the old Worth Matravers to Kimmeridge road, and is covered by debris from the higher cliffs: at the eastern end, the more clayey lowest part of the sequence crops out on a poorly accessible cliff (Figure 6). About 10m above the Cidarid Siltstone, a bed of organic-rich mudstone (the lower bituminous bed) a few centimetres thick forms a prominent rib underlain by two closely spaced siltstone ribs. The organic-rich bed weathers to a rotted paper shale with gypsum-coated surfaces and traces of a pyritised bivalve and ammonite fauna. 


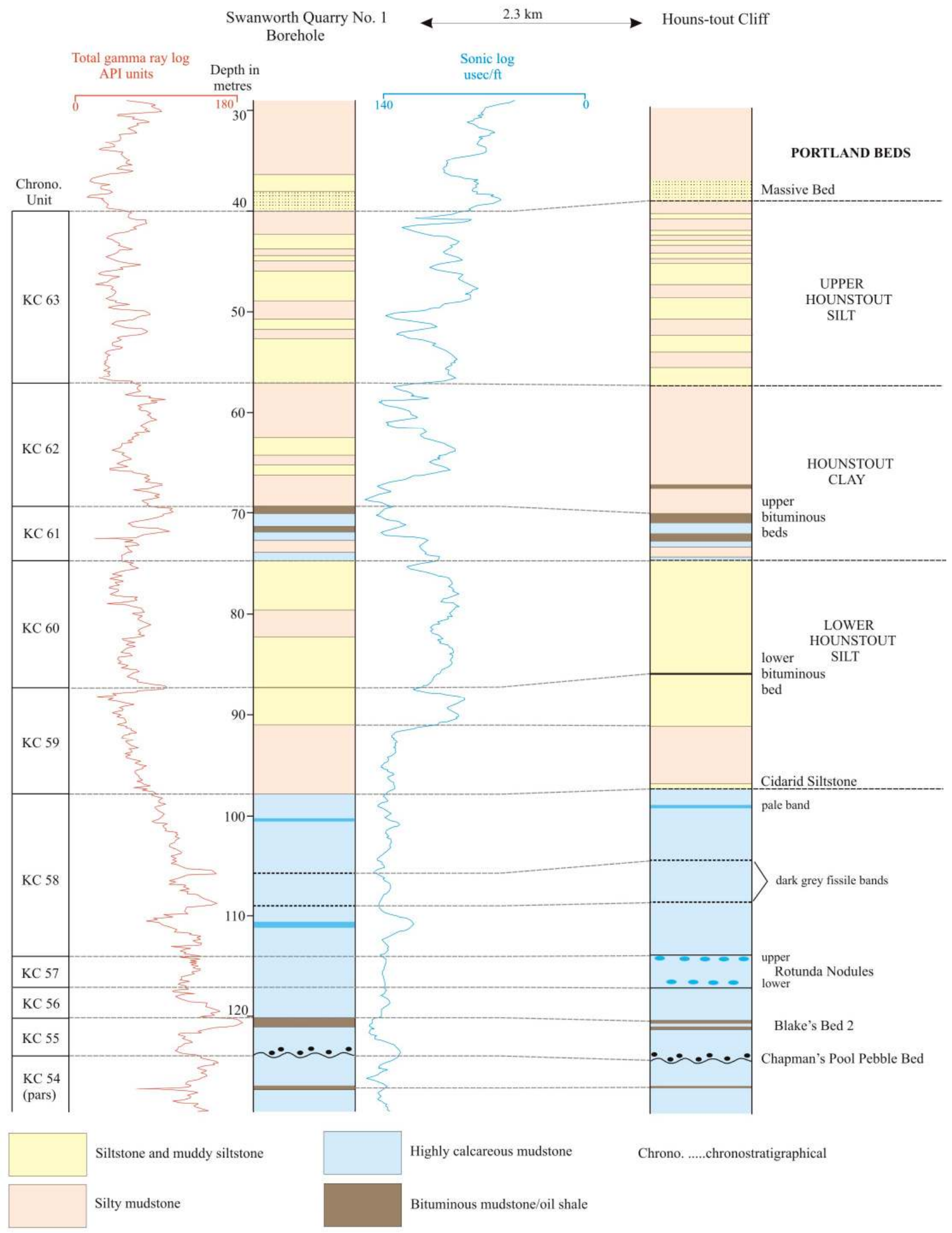

Figure 3. Comparison of the Kimmeridge Clay sequence above the Chapman's Pool Pebble Bed at Houns-tout/Chapman's Pool with that proved in the Swanworth Quarry No. 1 Borehole. 
Above this, seven rhythms of siltstone/muddy siltstone weather out on a steep slope as distinctive pale and dark bands (Figure 6) that form a readily recognisable correlative link between the eastern and western Houns-tout exposures.

The silt-dominated rhythms are overlain by pale, highly calcareous mudstones with two tough bituminous beds (the upper bituminous beds) that crop out as fissile, heavily stained ribs. These form a prominent lip in the eastern sections, above which much of the remainder of the Hounstout Clay is landslipped and/or covered by Portland Group debris. The whole of the Hounstout Clay is exposed at the western end of the Houns-tout cliff, but in deeply weathered sections. Parts of the Hounstout Clay, including the bituminous beds, are exposed in landslipped masses below Pier Bottom [958 760] (Figure 2), where they have yielded Fittoni Zone ammonites (Cope, 1978). The Upper Hounstout Silt consists of about $18 \mathrm{~m}$ of siltstones and muddy siltstones with thin interbeds of silty mudstone. In the central Houns-tout cliff, their base is locally marked by a prominent line of seepage, but this is only one of a number of seepage lines which might correlate with the "upper seepage" of Cope (1978).

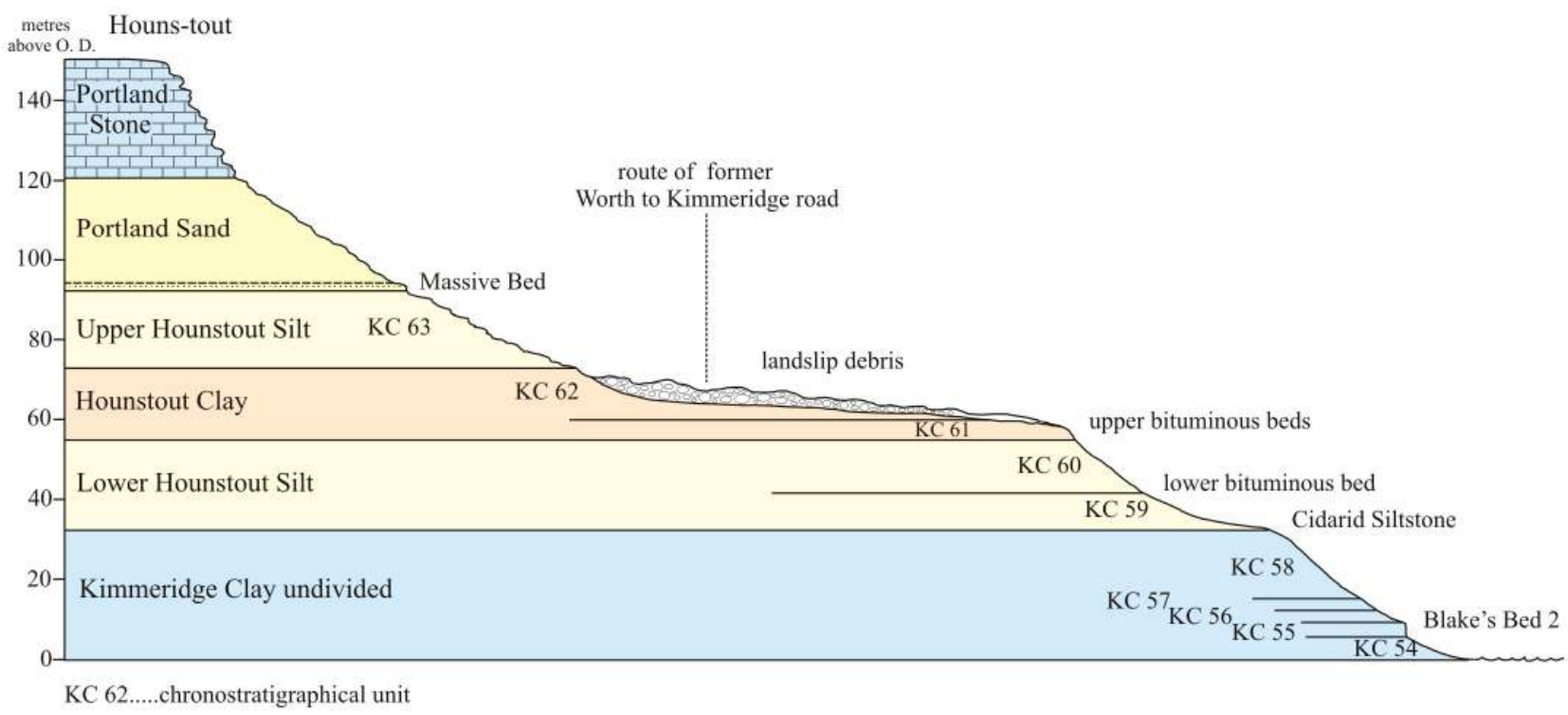

Figure 4. Sketch section through the Houns-tout eastern and lower cliffs showing the relationships of the more durable horizons to the topography.

Blake (1880) included the beds referred to here as the Upper Hounstout Silt in the Portland Sand on lithological grounds. Townson (1975, Table 1) included the Rhynchonella Marls, Hounstout Clay and Houstout Marl of Arkell (1933), the equivalents of the part of the Lower Hounstout Silt, the Hounstout Clay and the Upper Hounstout Silt of the present work, in his Portland Sand Formation. His formation boundary, "a mappable change from argillaceous sands and silts to shale" $34 \mathrm{~m}$ below the Massive Bed could not be matched with any marked lithological change in 
the present work. Arkell's (1933) revision of Blake's (1880) boundary upwards to the base of the Massive Bed (following Strahan, 1898 and most later authors) remains the most distinctive bed in a relatively uniform, silt-dominated unit at Houns-tout.

\section{Gad Cliff.}

The whole of the Rotunda and Fittoni zones is exposed in the vicinity of Wagon Rock [880 794] below Gad Cliff, albeit in small, deeply weathered outcrops that are separated by landslips and collapsed masses of Portland Stone debris. The sections are closer to the vertical limb of the Purbeck Monocline than those at the Houns-tout and are, in consequence, markedly thinner. The beds dip at $25^{\circ}$ to $30^{\circ}$ and are probably affected by minor faults and shearing. The lowest part of the sequence (KC 54 to 58), up to the lower part of the Lower Hounstout Silt, can be matched in detail with the type section (Figure 5). The higher sections contain lithologies and faunas that are similar to parts of the Lower Hounstout Silt, Hounstout Clay and Upper Hounstout Silt, but they are too deeply weathered and subject to mass movement to be correlated in detail with the Houns-tout section.

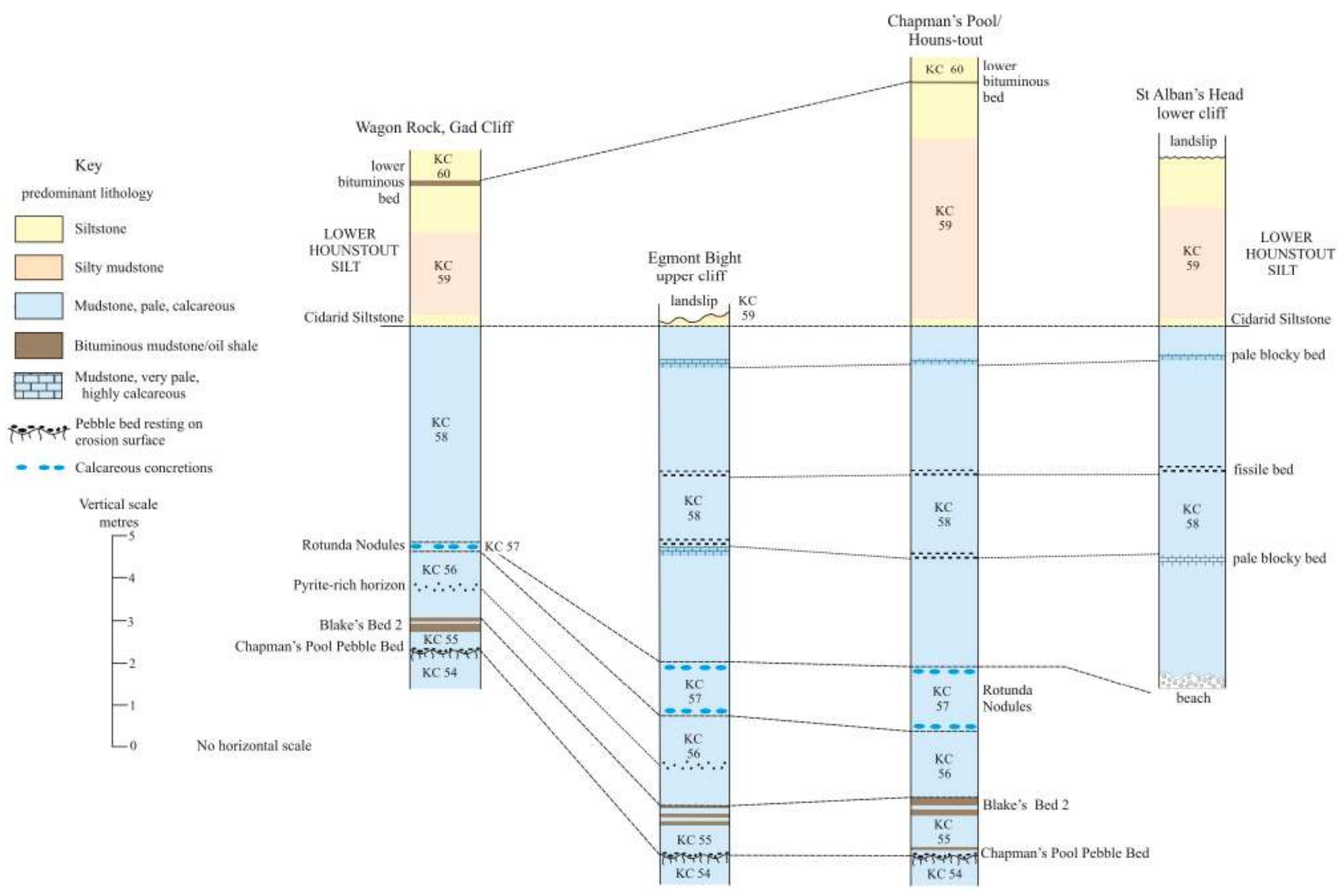

Figure 5. Correlation of certain marker beds between Gad cliff and St Alban's Head. 


\section{Dungy Head}

Arkell (1935, p. 321-322, Beds 1 to 3) recorded about 18m (58ft) of "black sandy marls, sand and sandstone" in the lower part of the Portland Group cliff [817 798] below Dungy Head, which he interpreted as the lowest part of the Portland Sand. The subsequent record by Cope (1978, p.528) of a specimen of Virgatopavlovia fittoni in a cementstone nodule at the top of this sequence and of Albani Zone ammonites in the overlying beds, suggests correlation of Arkell's Bed 3 with the Hounstout Silt. The sections are now poorly exposed and deeply degraded. They show up to $4 \mathrm{~m}$ of deeply weathered siltstone and silty mudstone close below the base of the Portland Sand that are probably the correlative of part of the Upper Hounstout Silt.

\section{Ringstead Bay and Black Head.}

Arkell (1947, p.82) recorded the following section (summarised and metricated here) in the highest part of the Kimmeridge Clay below the Portland Group cliff below Holworth House [7620 8155] above Ringstead Bay.

\section{Portland Sand}

....18.3m seen

\section{Kimmeridge Clay}

Clay with two cementstone horizons in lower part; Pavlovia in lowest $1.5 \mathrm{~m}$

Phosphatic Nodule Bed with common belemnites and phosphatic moulds of bivalves and 'pavlovid' ammonite body chambers

Clay and bituminous clay with Pavlovia

Phosphatic Nodule Bed, similar to above and with same fauna .... $0.3 \mathrm{~m}$

Clays and shales with Paravirgatites and Pectinatites .... $24.8 \mathrm{~m}$

White Stone Band $0.6 \mathrm{~m}$

This is probably the same section as that figured by Arkell (1947, Plate XI A). The original photograph for this plate (British Geological Survey A1367) shows much of the Kimmeridge Clay sequence to be obscured by Portland Group debris, and the remainder to have steep landward dips that suggest landslip disturbance. Part of the sequence is still visible, but much of it is not, due to subsequent movements within the landslip. The present exposure includes patches of the higher pebble bed overlain by patches of up to $10 \mathrm{~m}$ of deeply weathered, pale grey, calcareous mudstone with traces of rotted 'pavlovids' and bivalves. Patches of loose pebbles also occur a few metres lower. The section is now highly degraded, but it is clear that none of it is in situ. The highest Kimmeridge Clay outcrop is close below the Portland Group cliff, and there is no room for a Hounstout Silt outcrop. Arkell's section was probably about $100 \mathrm{~m}$ west of the present exposures and clearly exposed higher parts of the Kimmeridge Clay. However, these too appear to have been 
in a disturbed area: it is unlikely that it was ever possible to be sure if there were two separate pebble beds rather than one repeated by landslip.

The lithologies and fauna of both pebble beds can be closely matched with those of the Chapman's Pool Pebble Bed. The lithologies of the overlying mudstones currently exposed are similar to those of the beds between the pebble bed and the Cidarid Siltstone (KC 55 to 58), but no higher. The Rotunda Nodules, a distinctive and durable lithology at Chapman's Pool and Gad Cliff, have not been recorded at this locality. Arkell's thickness for the beds between his lower pebble bed and the White Stone Band, the highest unambiguously identifiable marker band in the underlying succession, is much reduced in comparison with that of the Kimmeridge area. This is in accord with what is known of the thinning of the Kimmeridge Clay as the axis of the Purbeck Monocline is approached. The Kimmeridge Clay sequence below the White Stone Band at Ringstead Bay is only $27 \%$ of the thickness of the comparable beds at Kimmeridge Bay (Cox and Gallois, 1981).

At Black Head [725 821], where the Kimmeridge Clay is unconformably overlain by the Cretaceous Gault Formation, Arkell (1947, p. 85) perceptively noted that the phosphatic nodule beds seen at Ringstead Bay (here interpreted as the Chapman's Pool Pebble Bed) had not quite been reached, but that retreat of the cliffs might be expected to expose them in a few years. Patches of the pebble bed, with its characteristic abundance of oysters, Pachyteuthis and phosphatic-pebble casts of bivalves and 'pavlovid' body chambers, now occur in the highest part of the section, close below the unconformity. Nearby exposures of the basal Gault pebble bed at Goggins Barrow [732 819] are lithologically different and contain an abundant Albian fauna.

\section{Isle of Portland.}

The Kimmeridge Clay is poorly exposed in the Isle of Portland where it is mostly obscured by landslip or by debris from the overlying Portland Group and Portland Stone quarry spoil. Sections in the highest part of the Kimmeridge Clay have been recorded from time to time, notably below West Weare Cliff [682 723] where Arkell (1933) recorded up to 13m (40ft) of "black sandy marls" of the Lower Black Nore Beds. Salfeld (1914) recorded 'pavlovid' ammonites from the underlying mudstones (as loose specimens), and Cope (1978, p.528) identified Virgatopavlovia fittoni from a slipped mass of Lower Black Nore Beds at beach level at Tar Rocks [681 725]. The latter section is now badly degraded and the sequence recorded by House (1958, fig. 14) is no longer visible. It seems likely that representatives of parts of KC 58 to 63 have at some time been exposed on this west side of the island, but in deeply weathered sections. 
Representatives of KC 54 to 56 are exposed in a low cliff [706 772] on the east side of the island below Grove Point, where the following section was recorded:

KC 56: Mudstone, pale grey, calcareous with subconchoidal weathering; common Pachyteuthis, crushed 'pavlovids' and bivalves in lower part .....3.50m seen

KC 55: Mudstone, brownish grey, organic rich; deeply weathered, fissile; probable equivalent of Blake's Bed 2 at Chapman's Pool ...... $0.50 \mathrm{~m}$ Mudstone, pale and medium grey, calcareous; shelly with abundant 'pavlovids' and bivalves, and common Pachyteuthis ....1.10m

Chapman's Pool Pebble Bed; calcareous mudstone crowded with crushed bivalves and shell debris including whole and crushed oysters, abundant large and small, crushed 'pavlovids' and abundant Pachyteuthis; common phosphatised bivalves and body chambers of 'pavlovids' in lower part; patchily phosphatised burrows and partially phosphatised bivalves in life position extend down from surface at base ....0.30m

KC 54: Mudstone, pale grey calcareous .... $0.3 \mathrm{~m}$ seen

A well-preserved plesiosaur, Colyombosaurus trochanterius (Owen), was excavated from a shell-rich layer at or close to this site (Brown, 1983). The associated fauna from the excavation was described by Palmer (1987) who reported a rich and diverse assemblage that included eight species of fish, echinoids, gastropods, scaphopods, sixteen species of bivalve, brachiopods, cirripedes, ostracods, foraminifera, common Pachyteuthis, and common 'pavlovids' including Pavlovia rotunda. He correlated the plesiosaur horizon at Grove Point with the basal beds of the Rotunda Zone at Chapman's Pool. The diversity of the fauna combined with the presence of P. rotunda and common Pachyteuthis confirm this and indicate correlation with the Chapman's Pool Pebble Bed. An oil shale a little higher in the sequence at Grove Point is the probable correlative of Blake's Bed 2.

\section{OTHER AREAS}

The youngest part of the Kimmeridge Clay has no current outcrop apart from those described above. Complete sequences have been proved at depth in hydrocarbon-exploration boreholes in the Isle of Purbeck and the Isle of Wight south of the Purbeck-Wight Monocline, in parts of the Hampshire Basin and, more extensively, beneath the Weald. However, none of these boreholes cored the highest part of the Kimmeridge Clay, and the stratigraphy can only be deduced from downhole geophysical logs (Taylor, Sellwood, Gallois \& Chambers, 2000). Farther north, adjacent to the London Platform massif which acted as a positive area during Kimmeridgian times, the 
Kimmeridge Clay succession above the Pectinatus Zone contains progressively more erosional breaks and becomes more arenaceous.

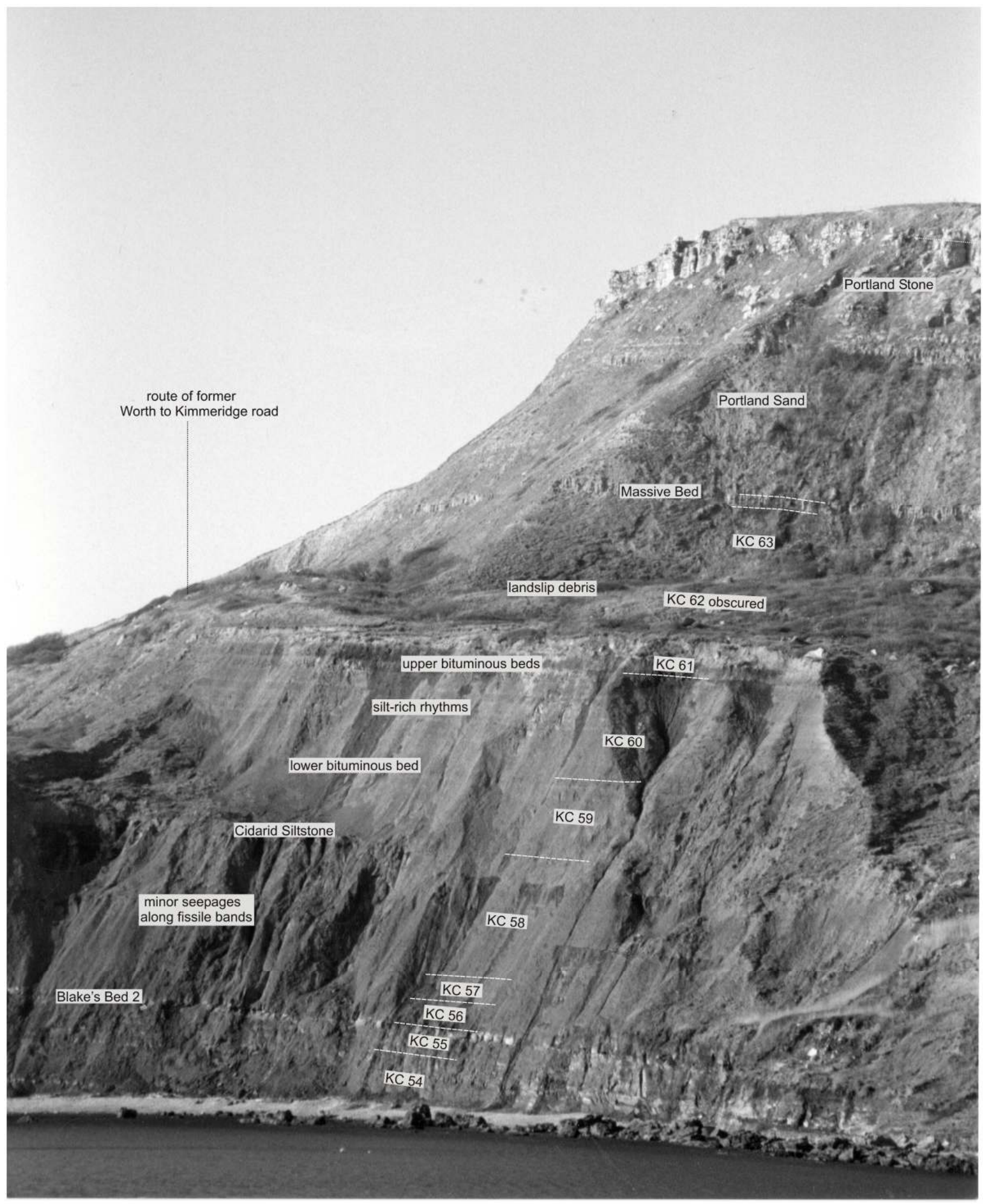

Figure 6. Houns-tout eastern and lower cliffs viewed from Pier Bottom: the more prominent marker bands form ribs and/or mark changes in slope angle. 
The most complete continuously-cored sequence recorded to date outside south Dorset is that in the BGS Tisbury Borehole [ST 9361 2908]. This proved representatives of the Pallasioides, Rotunda and Fittoni zones in predominantly silty facies and with three major sedimentary breaks. The lowest of these is marked by the Lower Lydite Bed, a phosphatic pebble bed that can be traced around much of southern and western margins of the London Platform. The next highest break is marked by the Chapman's Pool Pebble Bed. This probably has an extensive subcrop south of the London Platform, but has not previously been recognised outside south Dorset. Close to the edge of the platform, for example in the BGS continuously cored boreholes at Warlingham [TQ 3476 5719] (Callomon \& Cope, 1971) and Hartwell [SP 7926 1223] (Cox, Gallois \& Sumbler, 1994), phosphatised debris from the pebble bed has probably been incorporated in the Upper Lydite Bed at the base of the Portland Group (Figure 7).

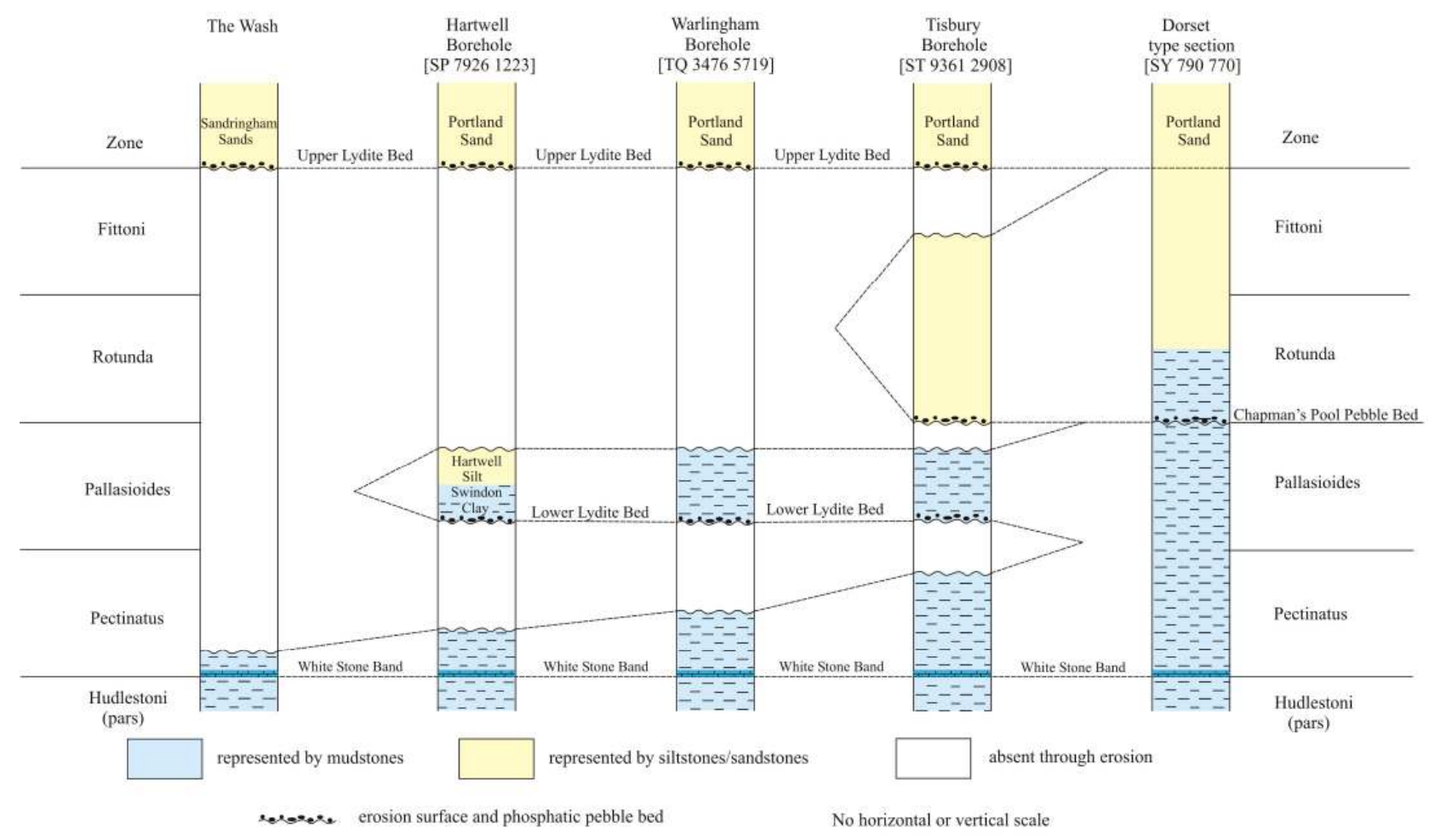

Figure 7. Correlation of the Pectinatus to Fittoni zones in south Dorset with those elsewhere in southern England.

\section{STAGE NOMENCLATURE AND INTERNATIONAL CORRELATION}

There is currently no universally accepted agreement on the Standard Stages of the latest Jurassic, the reasons for which have been well documented (see Cope, 1996 for summary). Different schemes exist for the Tethyan (Tithonian Stage) and Boreal (Volgian Stage) faunal realms. The nomenclature is further complicated in Britain and northern France (Sub-Boreal Province) by the recognition of a Portlandian Stage, the base of which is taken at markedly different stratigraphical levels in Britain and France. This 
has resulted in different sensu anglico and sensu gallico definitions for the Kimmeridgian and Portlandian stages. Following the ratification of the Tithonian Stage as the World Standard for the latest Jurassic by the Jurassic Subcommission in 1991, the upper limit of the Kimmerdigian Stage on which it rests has been defined at a stratigraphical level at or close to the top of the Kimmeridgian Stage sensu gallico. This has led Cope (1995) to suggest that the current Upper Kimmeridgian Substage sensu anglico should be renamed the Bolonian Stage and that it and the overlying Portlandian Stage sensu anglico should be retained as local Secondary Standard Stages. The junction of these two proposed stages would be at the base of the Albani Zone, which is currently taken to be coincident with the base of the Massive Bed in Houns-tout Cliff (Cope, 1978).

The Rotunda and Fittoni zones have only been recognised within the Sub-Boreal faunal province in Britain and northern France, but suggested correlations have been made with parts of the Volgian and Tethyan zonal schemes (Table 2). Long-distance correlation is difficult at this stratigraphical level in Europe partly because of the provincialism of the ammonite assemblages, but mainly because there are few unbroken marine sequences for comparison (see Cope et al., 1980, pp. 86-87 for discussion). The ammonites at this stratigraphical level in Dorset have affinities at the generic level with those of the Boreal (Volgian) assemblages of the Russian Platform (Gerasimov \& Mikhailov, 1966) and East Greenland (Callomon \& Birkelund, 1982), which has enabled broad correlations to be made between the various local zonal schemes (Hantzpergue, et al., 1998).

No satisfactory correlation has yet been made between the Rotunda and Fittoni zones and the zones of the Tithonian Stage. However, suggested correlations between some of the more southerly Boreal Province successions, such as those of the Caucasus (Sei \& Kalacheva, 1997) and those of northern Tethys (Tavera et al., 1996), have provided an indirect link between the Dorset and Tethyan successions against which correlations based on sequence stratigraphy, cyclostratigraphy and magnetostratigraphy can be tested.

The faunal provincialism in the latest Jurassic may have resulted from widespread tectonic activity (the late Cimmerian Orogeny of Stille, 1924) that caused seaways to become closed or too restricted for large-scale ammonite dispersal. Uplift and erosion around the edges of all but the deepest sedimentary basins has meant that all the outcrop sections in the beds of this age in Britain except for the Houns-tout/Chapman's Pool section contain major sedimentary breaks. The same is true of their equivalents on the north French coast, on the Russian Platform and in much of southern Europe. Attempts have, therefore, been made to effect correlations between the faunal provinces on the identification of what are presumed to be widespread isochronous events. For 
example, Casey (1971) noted a hiatus at the Middle/Upper Volgian boundary over much of NW Europe and correlated this with the Rotunda Nodules at Chapman's Pool. Neither the lower nor the upper band of the Rotunda Nodules is associated with a sedimentary break in Dorset. However, the Rotunda Nodules lie only $7 \mathrm{~m}$ above the major sedimentary break that is represented by the Chapman's Pool Pebble Bed and which marks the incoming of the distinctive Rotunda Zone faunas. Casey's correlation, with slight modification in Dorset, may, therefore, provide a key interbasinal link at this stratigraphical level.

\begin{tabular}{|c|c|c|c|c|c|c|}
\hline \multicolumn{3}{|c|}{ Sub-Boreal Province } & \multirow{2}{*}{\multicolumn{2}{|c|}{$\begin{array}{l}\text { Boreal Province } \\
\text { Russian Platform }^{1}\end{array}$}} & \multirow{2}{*}{\multicolumn{2}{|c|}{$\begin{array}{l}\text { Tethyan Province } \\
\text { Southern Europe }{ }^{2}\end{array}$}} \\
\hline England & & Northern France & & & & \\
\hline Portlandian (nars) & \multirow{2}{*}{$\begin{array}{l}\text { Progalbanites } \\
\text { albani }\end{array}$} & \multirow{2}{*}{$\begin{array}{c}\text { Portlandien } \\
\text { superieur (pars) }\end{array}$} & \multirow{4}{*}{$\begin{array}{l}\text { Middle } \\
\text { Volgian } \\
\text { (pars) }\end{array}$} & Epivirgatites nikitini & \multirow{4}{*}{$\begin{array}{c}\text { Upper } \\
\text { Tithonian (pars) }\end{array}$} & Durangites \\
\hline & & & & & & \multirow{2}{*}{$\begin{array}{l}\text { Paraulacosphinctes } \\
\text { transitorius }\end{array}$} \\
\hline \multirow{3}{*}{$\begin{array}{c}\text { Upper } \\
\text { Kimmeridgian } \\
\text { (pars) }\end{array}$} & $\begin{array}{l}\text { Virgatopavlovia } \\
\text { fittoni }\end{array}$ & \multirow{3}{*}{$\begin{array}{l}\text { Portlandien } \\
\text { inferieur (pars) }\end{array}$} & & Virgatites virgatus & & \\
\hline & $\begin{array}{c}\text { Pavlovia } \\
\text { rotunda }\end{array}$ & & & Dorsoplanites panderi & & Simplisphinctes \\
\hline & $\begin{array}{c}\text { Pavlovia } \\
\text { pallasioides }\end{array}$ & & $\begin{array}{c}\text { Lower } \\
\text { Volgian (pars) }\end{array}$ & $\begin{array}{l}\text { Ilowaiskya } \\
\text { pseudoscythica }\end{array}$ & $\begin{array}{c}\text { Middle } \\
\text { Tithonian (pars) }\end{array}$ & Simoceras volense \\
\hline
\end{tabular}

1.....Based on Hantzpergue et al., 1998

2.....Based on Cecca \& Santantonio, 1989; and Tavera et al., 1996,

Table 2. Correlation of the biozones of the youngest Kimmeridgian sensu anglico with their presumed equivalents in the Boreal and Tethyan provinces.

\section{SUMMARY}

The youngest part of the Kimmeridge Clay and the Kimmeridgian Stage sensu anglico, the Rotunda and Fittoni zones, is complete and wholly exposed at only one locality in Britain, that at Houns-tout Cliff/Chapman's Pool in south Dorset. The equivalent sequences in eastern England and northern France contain major sedimentary breaks and include coarser lithologies in which few ammonites are preserved. Although deeply weathered in part, the Houns-tout/Chapman's Pool sections remain the most complete yet described in the Sub-Boreal Province at this stratigraphical level, and are a key locality for international correlation. However, their palaeontology is still insufficiently well described for the sections to achieve their full potential as an international standard. No specifically determinable ammonite has been recorded from about $20 \mathrm{~m}$ of strata between the youngest recorded Rotunda Zone fauna and the oldest Fittoni Zone fauna, and from about $4 \mathrm{~m}$ between the youngest Fittoni Zone and the oldest Albani Zone. The non-ammonite fauna remains virtually undescribed. In addition, the definition of the Fittoni Zone is based on a small number of specimens from two localities (Houns-tout and Pier Bottom) which have not been accurately correlated with one another. 
Correlation of a revised description of the lithostratigraphy of the outcrop section with that proved nearby in a continuously cored borehole has confirmed the lateral persistence of several marker bands. The availability of a lithologically more detailed description of the type section than that currently published, together with its correlation with other current exposures of these beds on the south Dorset coast, will provide a framework for future collecting.

\section{ACKNOWLEDGEMENTS}

The authors are grateful to Ellis Owen for his identification of the rhynchonellid brachiopods; to the Steering Committee of the NERC Rapid Global Geological Events (RGGE) Project for access to data from the Swanworth Quarry No.1 Borehole; and to Dick Edwards and Mike Sumbler for their critical comments on the manuscript. This paper is published by permission of the Director, British Geological Survey (NERC).

\section{REFERENCES}

Arkell, W. J. 1933. The Jurassic System in Great Britain. Clarendon Press, Oxford.

Arkell, W. J. 1935. The Portland Beds of the Dorset mainland. Proceedings of the Geologists' Association, 46, 301-347.

Arkell, W. J. 1947. The geology of the country around Weymouth, Swanage, Corfe, and Lulworth. Memoirs of the Geological Survey of Great Britain. HMSO, London.

Blake, J. F. 1875. On the Kimmeridge Clay of England. Quarterly Journal of the Geological Society of London, 31, 196-233.

Blake, J. F. 1880. On the Portland Rocks of England. Quarterly Journal of the Geological Society of London, 36, 196.

Brown, D. S. 1983. Discovery of a specimen of the plesiosaur Colymbosaurus trochanterius (Owen) on the Isle of Portland. Proceedings of the Dorset Natural History and Archaeological Society, 105, 170.

Buckman, S. S. 1926. Type ammonites. Thame and London.

Callomon J. H. \& Birkelund, T. 1982. The ammonite zones of the Boreal Volgian in East Greenland. In (Embry, A. F. \& Balwill, H. R.; eds) Arctic Geology and Geophysics. Canadian Society of Petroleum Geologists, Memoir 8, 349-369.

Callomon, J. H. \& Cope, J. C. W. 1971. The stratigraphy and ammonite succession of the Oxford and Kimmeridge clays in the Warlingham Borehole. Bulletin of the Geological Survey of Great Britain, No. 36, 147-176. 
Callomon, J. H. \& Cope, J. C. W. 1995. The Jurassic geology of Dorset. In (Taylor, P. D.; ed) Field Geology of the British Jurassic. Geological Society, London, 51-103.

Casey, R. 1971. Facies, faunas and tectonics in late Jurassic early Cretaceous Britain. In (Middlemiss, F. A. \& Rawson, P. F.; eds) Faunal Provinces in space and time. Seel House Press, Liverpool, 153-168.

Cecca, F. \& Santantonio, M. 1989. Kimmeridgian and Lower Tithonian ammonite assemblages in the Umbria-Marches-Sabine Appenines (Central Italy). In ( Rocha, R. B. \& Soares, A. F.; eds) Second International Symposium on Jurassic Stratigraphy, 1988, 525-542.

Cope, J. C. W. 1978. The ammonite faunas and stratigraphy of the upper part of the Upper Kimmeridge Clay of Dorset. Palaeontology, 21, 469-533.

Cope, J. C. W. 1995. Towards a unified Kimmeridgian Stage. Petroleum Geoscience, 1, 351-354.

Cope, J. C. W. 1996. The role of the Secondary Standard in stratigraphy. Geological Magazine, 133, 107-110.

Cope, J. C. W., Duff, K. L., Parsons, C. F., Torrens, H. S., Wimbledon, W. A. \& Wright, J. K. 1980. A correlation of the Jurassic rocks in the British Isles. Part Two: Middle and Upper Jurassic. Geological Society, London, Special Report No. 15, 109pp.

Cox, B. M. \& Gallois, R. W. 1981. The stratigraphy of the Kimmeridge Clay of the Dorset type area and its correlation with some other Kimmeridgian sequences. Institute of Geological Sciences Report No. 80/4, 1-44.

Cox, B. M., Gallois, R. W. \& Sumbler, M. G. 1994. The stratigraphy of the BGS Hartwell Borehole, near Aylesbury, Buckinghamshire. Proceedings of the Geologists' Association, 105, 209-224.

Gallois, R. W. 1998. The stratigraphy of and well-completion reports for the Swanworth Quarry No. 1 and No. 2 and Metherhills No.1 boreholes (RGGE Project), Dorset. British Geological Survey Technical Report WA/97/91.

Gallois, R. W. 2000. The stratigraphy of the Kimmeridge Clay Formation (Upper Jurassic) in the RGGE Project boreholes at Swanworth Quarry and Metherhills, south Dorset. Proceedings of the Geologists' Association, 111, 265-280.

Gerasimov, P. A. \& Mikhailov, N. P. 1966. The Volgian Stage and the standard scale for the upper series of the Jurassic System. Izvestia Akademiya Nauk SSSR, Ser. Geol., No. 2, 118-138.

Hantzpergue, P., Baudin, F., Mitta, V., Olferiev, O. \& Zakharov, V. 1998. The Upper Jurassic of the Volga Basin: ammonite biostratigraphy and occurrence of organic-carbon rich facies. Correlations between boreal-subboreal and submediterranean provinces. In (Crasquin-Soleau, S. \& Barrier, E.; eds) Peri-Tehys Memoir 4: epicratonic basins of Peri-Tethyan platforms. Memoires du Muséum National d'Histoire Naturelle, 9-33. 
House, M. R. 1958. Geology of the Dorset coast from Poole to the Chesil Beach. Geologists' Association Guide No. 22, $21 \mathrm{pp}$.

Palmer, C. P. 1987. The Kimmeridgian fauna associated with the Portland plesiosaur. Proceedings of the Dorset Natural History and Archaeological Society, 109, 109-112.

Salfeld, H. 1914. Die Gliederung des oberen Jura in nordwesteuropa Neues Jahrbuch fur Mineralogie, Geologie und Palaeontologie Beilage-Band, 37, 125-246.

Sei, I. I. \& Kalacheva, E. D. 1997. The Jurassic-Cretaceous boundary in the Boreal Realm (Biostratigraphy and Boreal-Tethyan correlation). Stratigraphy and Geological Correlation, 5, 3854.

Stille, H. 1924. Grundfragen der vergleichenden Tektonik. Berlin.

Strahan, A. 1898. The geology of the Isle of Purbeck. Memoirs of the Geological Survey of Great Britain. HMSO, London.

Tavera, J. M., Oloriz, F., Company, M. \& Checa, A. 1996. Mediterranean ammonites and the Jurassic-Cretaceous boundary in southern Spain (Subbetic Zone). Acta Geologica Hungaria, 29, 151-159.

Taylor, S. P., Sellwood, B. W., Gallois, R. W. \& Chambers M. H. 2000. A sequence stratigraphy of the Kimmeridgian and Bolonian stages (late Jurassic): Wessex-Weald Basin, southern England. Journal of the Geological Society, London, 157, 000-00.

Townson, W. G. 1975. Lithostratigraphy and deposition of the type Portlandian. Journal of the Geological Society, London, 131, 619-638. 